\title{
Yarının Yüksek Performanslı Liflerine Doğal Bir Yaklaşım: Balık Asalağı Salgı Lifleri
}

\author{
Ece KALAYCI, O. Ozan AVINÇ*, Arzu YAVAŞ \\ Pamukkale Üniversitesi, Tekstil Mühendisliği Bölümü, Denizli, 20070
}

\begin{abstract}
ÖZET
'Hiperotreti' olarak da bilinen balık asalakları kendilerini tehlike altında hissettiklerinde vücutları üzerinde bulunan salgı bezlerinden mukusa benzer bir sıvı salgılar. Bu salgı içerisinde bulunan lifler bugüne dek bilinen en tok lifler arasındadırlar. Yaklaşı $15 \mathrm{~cm}$ uzunluğunda ve ortalama 1-3 $\mu \mathrm{m}$ çapında olan bu lifler birçok doğal ve sentetik liften daha üstün özelliklere sahiptir. Balık asalağı salgısı lifleri yapısal özellikleri ile yün ve saç gibi $\alpha$-keratin içeren diğer doğal protein liflerinden ayrılmaktadır. Kopma mukavemeti de yüksek olan balık asalağı salgısı lifleri oldukça iyi bir esneme kabiliyetine sahiptir. Henüz ticari olarak üretilemeyen bu lifler üzerinde araştırmalar halen devam etmektedir.
\end{abstract}

Anahtar kelimeler: Balık asalağı salgısı lifi, Balık asalağı, Hiperotreti, Yüksek performanslı lif, Doğal protein lifi

\section{A Natural Approach To Tomorrow's High Performance Fibers: Hagfish Slime Fibers}

\begin{abstract}
Hagfishes, also known as 'hyperotreti', release a mucus-like slime from their glands located on their body when they feel threatened. This slime contains fibers that are one of the toughest fibers known to date. Those fibers are approximately $15 \mathrm{~cm}$ long and $1-3 \mu \mathrm{m}$ in width and have superior properties to most of natural and synthetic fibers. Hagfish slime fibers differ with their structural features from other natural protein fibers which contain $\alpha$-keratin such as wool and hair. With a high breaking strength, these fibers also exhibit considerably good elongation. The hagfish slime fibers are not commercially manufactured yet while research is still in progress.
\end{abstract}

Keywords: Hagfish slime fiber, Hagfish, Hyperotreti, High performance fiber, Natural protein fiber, Regenerated protein fiber

\section{GIRIŞ}

Dünyanın en büyük endüstrilerinden biri olan ve her geçen gün kullanım alanını genişleten tekstil sektörü hammadde ihtiyacını çoğunlukla sentetik lifler ile karşılamaktadır. Fakat sentetik liflerin petrol esaslı olması ve petrol rezervlerinin gün geçtikçe azalması, bu liflerin sürdürülebilirliği açısından büyük bir problem oluşturmaktadır [1,2]. Günümüzde birçok endüstri gibi tekstil endüstrisi de sürdürülebilir hammadde ve yöntem arayışı içerisindedir. Konvansiyonel tekstil üretiminde genellikle sentetik liflere tercihen doğal liflerin ya da doğal kökenli liflerin kullanılması, konvansiyonel tekstil ürünlerinin üretiminin sürdürülebilir hale getirilebilmesinde önemli bir rol almaktadır [2]. Ortalama tekstil özelliklerine sahip sentetik liflerin muadili doğal ya da doğal kökenli liflerin bulunması pek zor değildir. Ancak, yüksek performanslı sentetik liflerin yerine doğal ya da doğal kökenli liflerden bir alternatif yaratmak oldukça güçtür.

Yüksek performans özelliklerine sahip doğal esaslı protein lifi olarak akla gelen ilk isim örümcek ipeği lifleridir [3]. Geçtiğimiz on y1lda oldukça yaygınlaşan bu lifler doğal ya da rejenere olarak üretilebilmektedir. Fakat örümcek ipeği liflerinin üretimi, tekstil sektöründe ihtiyaç duyulan yüksek performanslı lif miktarı ile kıyaslandığında oldukça sınırlı kapasitededir. Bu sebeple bilim dünyası uzun yıllardır yüksek performanslı liflere doğal bir kaynak arayışı içerisindedir. İlk olarak 1941 yılında "Hyperotreti (hagfish)" adı verilen deniz canlıların vücutlarından salgılanan sıvı 
içerisinde oldukça yüksek performans özelliklerine sahip protein lifli yapıların bulunduğu kaydedilmiştir $[1,2,4,5]$. Derin sularda yaşayan bu deniz canlılarının tehlike anında vücudundan mukusa benzer yapıda bir sıvı salgıladığı ve bu sıvı içerisinde oldukça yüksek performans özelliklerine sahip liflerin bulunduğu belirtilmiş̧ir [2,4,6,7]. Günümüzde hala birçok bilimsel araştırmaya konu olan bu lifler henüz ticari olarak üretilebilmiş olmasa da, üzerinde çalışan bilim insanları çok kısa bir sürede bu liflerin hayatımıza gireceğini dile getirmektedir [2,4,6,7]. Bu derleme çalışmasında, balık asalağı salgısı içerisinde bulunan protein liflerinin yapısı, özellikleri, sürdürülebilir protein liflerinin üretimine biomimik etkisi ve bu liflerin geleceği konularına yer verilmiştir.

\section{BALIK ASALAĞI (HIPPEROTRETI)}

Çenesiz balıklar sınıfına ait olan balık asalaklarının (hagfish) yaklaşık 80 türü bulunmaktadır [8,9]. Genellikle soğuk sularda, 5000 metreye varan derinliklerde ve yumuşak deniz zeminin bulunduğu bölgelerde yaşamaktadırlar $[7,8,10]$. Omurgasız bir canlı olan balık asalağının türüne göre gri-maviden pembeye değişim gösteren yumuşak bir bedeni vardır [7]. İlkel bir kan dolaşım sistemine sahip olan bu deniz canlıları hem burunları hem de vücutları ile solunum yapabilmektedirler [7,8]. Görme yetileri gelişmiş olmamasına rağmen koku alma ve hissetme duyuları oldukça iyidir [7]. Deniz tabanındaki ölü balıklardan ya da derin sularda yaşayan büyük balıkların vücuduna başını sokarak beslenen balık asalakları, metabolizmalarının oldukça yavaş olması sayesinde besin tüketmeden aylarca hayatta kalabilmektedirler [8].

Balık asalaklarının vücudunun birçok yerinde her hangi bir tehlike anında salgıladığı sıvıyı vücudunun dışına ya da içe (kana) akıtan bezler bulunur [3,10,11] (Şekil 1). Sadece 0,1 saniye içerisinde litrelerce salgıyı etraflarına yayabilirler $[9,12]$. Mukusa benzer bir yapıda olan bu salgı saldırıda bulunan balıkların solungaçlarını tıkayarak, balık asalağının saldırıdan zarar görmesini engelleyebilmektedir [9,12-14].

Hayvanın toplam vücut ağırlığının \%3-4'ü kadar olan bu sıv1, üst deride bulunan salgı bezleri tarafindan üretilmektedir [11,15] (Şekil 1-a). Bu salg1 bezlerinin çeperinde sıralanan iki farklı hücre türü bulunmaktadır [1518]. Bu hücre türlerinden ilki tamamen balık asalaklarına özgü olan salgı lifi hücreleri (Gland Thread Cells-GTCs) olarak bilinen elips şekilli hücrelerdir $[5,9,15,16,18]$. Salg1 lifi hücrelerinin (GTC) içerisinde salgılanmaya hazır, ara filamentler (IFs-intermediate filaments) olarak bilinen oldukça sıkı şekilde sarılmış yumaklar şeklinde olan filament toplulukları bulunmaktadır (Şekil 1-b) [7,15,17-20]. Kasların uyarılması ile salgı bezlerini çevreleyen kasların kasılması sonucu her iki hücre tipi de salgı bezi içerisinden dar salgı bezi gözeneğinden dışarı atılmaya zorlanır. $\mathrm{Bu}$ sırada hücreleri çevreleyen plazma zarı yırtılır ve etraflarını çevreleyen deniz suyu ile hızlı şekilde etkileşmesi sağlanır (Şekil 1-c). Salgı bezi içerisindeki salgı lifi hücreleri (GTC) Şekil 2'de gösterilmiştir. Henüz olgunlaşmamış salg1 lifi hücreleri (GTC) salgı bezinin dış çeperine yakın yerlerde konumlanırken, olgun salgı lifi hücreleri (GTC) salgı bezinin ortalarında bulunmaktadır [9].

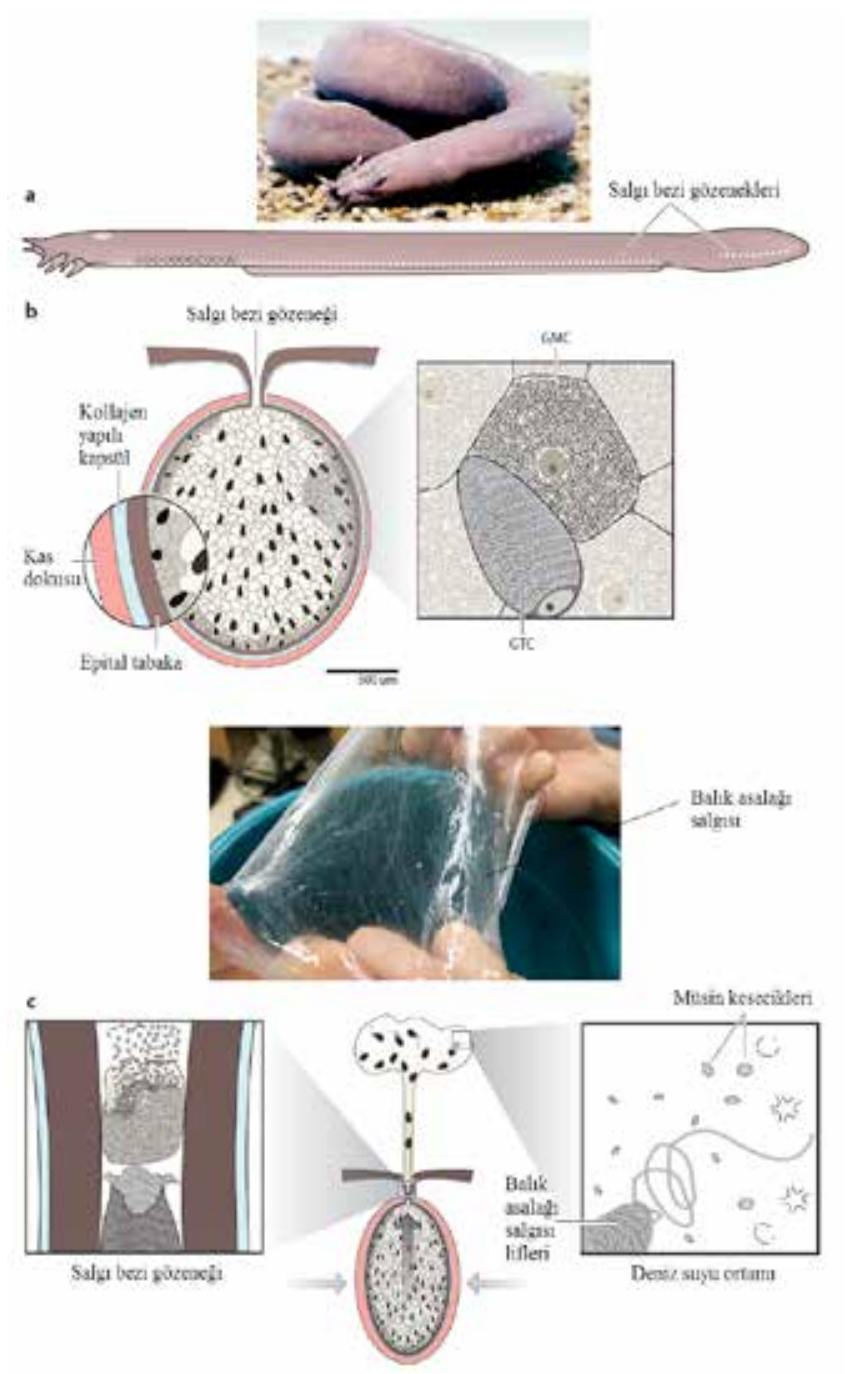

Şekil 1. Balık asalağının salgı bezlerinin morfolojisi ve anatomisi $[5,9,20-23]$.

Balık asalaklarının salgı bezlerinin barındırdığı diğer bir hücre türü de salgı mukus hücreleri (Gland Mucous CellsGMCs) olarak adlandırılan hücrelerdir [15-18,20]. Bu 
hücreler sümüksü (musin benzeri) glikoproteinler içeren çevresi zarla kaplı musin (sümük) kesecikleri üretirler [11,15] (Şekil 1-c). Balık asalaklarının salgı bezleri içerisindeki sıvı (eksüda), organik bir bileşik olan metilamin $\left(\mathrm{CH}_{3} \mathrm{NH}_{2}\right)$ bakımından oldukça zengindir. Bu sayede Salg1 lifi hücrelerinin (Gland Thread Cells-GTCs) ürettiği ara filamentlerin hücre içerisinde birbirlerine sarılı kaldığ düşünülmektedir [9].

Her hangi bir tehlike anında salgı bezlerini çevreleyen kas sisteminin kasılması, salgı bezlerinde hazır bulunan hem salgı lifi hücrelerinin (Gland Thread Cells-GTCs) hem de salgı mukus hücrelerinin (Gland Mucous Cells-GMCs) her ikisinin de salgı bezlerinden dışarı balık asalağını çevreleyen ortama salınmasına neden olmaktadır $[15,16,18]$. Salgı bezi gözeneklerinden dış ortama çıkarken dar gözenek yapısı ile GTC ve GMC hücrelerini çevreleyen hücre zarları parçalanır [24] ve hücreler deniz suyu içerisinde plazma zarını tamamen kaybederler. Hücre duvarı içerisinde sarmal bir demet şeklinde bulunan ara filamentler, zarın kaybolması ile toplam uzunluğu yaklaşık $15 \mathrm{~cm}$ 'i bulan 1-3 $\mu \mathrm{m}$ çapında lifler halinde serbest hale geçerler [3,10,13,17-19,24,25].

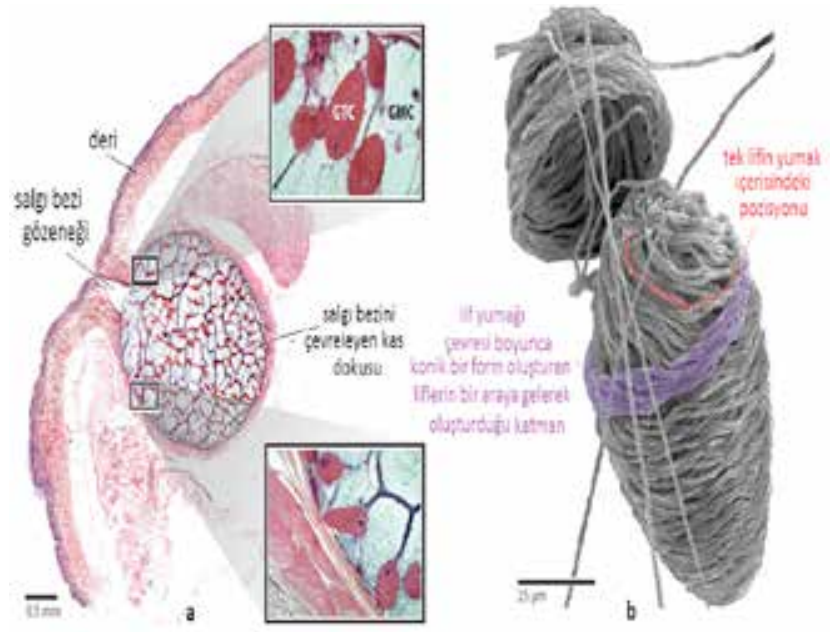

Şekil 2. (a) Balık asalaklarında bulunan salgı bezinin yapısı içerisinde GTC (salgı lifi hücreleri) ve GMC (Salg1 mukus hücreleri) hücrelerinin yeri, (b) Yarı açılmış lif yumağının SEM mikroskobu altındaki görüntüsü $[9,17,19,20,26]$

\section{BALIK ASALAKLARININ SALGILARINDA BULUNAN LIFLERİN YAPISI}

Balık asalakları başka birçok hayvanda da olduğu gibi her hangi bir tehlike anında vücutlarından mukusa benzer salg1 salgılar $[3,11,16,27]$. Fakat bu salgıyı diğer hayvanların salgıladığı sıvıdan ayıran en önemli özellik, içerisinde gözlemlenen liflerdir. $\mathrm{Bu}$ lifler, balık asalağının salgı bezlerinin çeperinde sıralanan Salg1 lifi hücreleri (Gland Thread Cells-GTCs) tarafindan üretilir ve çok sayıda keratin-benzeri ara filament proteinlerinin bir araya gelmesi ile oluşur $[16,24,28]$. Devamlı bir yapıya sahip olan bu lifler birbiri üzerine sarılarak Şekil 3'te gösterilen ara lifler topluluğunu meydana getirirler [16,24,28]. Elips şeklinde olup sarmal bir yapıya sahip olan bu lif topluluğu elipsin tabanından en üst noktasına kadar iç içe geçmiş konik formda lif eğrilerinden oluşur (Şekil 3-b ve Şekil 3-c) [9]. Şekil 3-a'da bu lif hücrelerinin gelişimi sırasında GTC çekirdeklerinin (nucleus) zamana bağlı boyut ve şekil değişimi gösterilmektedir $[9,17,19]$. Şekil 3-d'de ise balık asalağının salgı bezleri tarafindan üretilen sarmal yapılı lif hücrelerinin sitoplazma içerisindeki halinin SEM görüntüsü ve bu sarmal yapının salgı bezi duvarları içerisinde çözülürkenki görüntüsü verilmiştir [29]. Ayrıca olgun bir lif yumağı içerisinde iç içe geçmiş konik sarmal lif düzenine sahip liflerin çözülüp serbest hale geçmesinde, deniz suyunun hızlandırıcı bir etkiye sahip olduğu kaydedilmiştir [9].

GTC (salgı lifi hücreleri) tarafından üretilen salgı lifleri ara filament (Intermediate Filaments) ailesine ait $\alpha, \beta$, ve $\gamma$ olmak üzere üç farklı proteinden meydana gelmektedir. Daha sonra yapılan çalışmalarda, $\beta$ proteinin çok büyük olasılıkla protein sentezi işlemi sonrasında $\gamma$ proteinde oluşan modifikasyon sonucu oluştuğu keşfedilmiştir [30]. $\mathrm{Bu}$ modifikasyonunun nedeni kesin olarak açılanamasa da, $\gamma$ proteinin yüksek oranda treonin aminoasitleri içerdiği bilinmektedir [9].

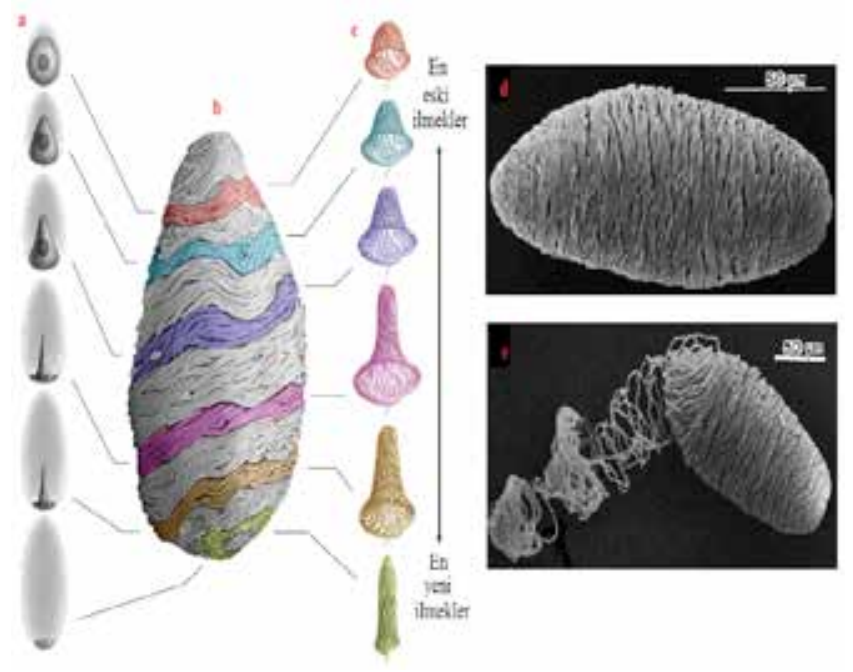

Şekil 3. GTC (salgı lifi hücreleri) içerisinde lif hücrelerinin zamana bağlı değişimini gösteren model (a-b-c) $[9,17,19]$, lif topluluğunun çözülmeden önceki (d) ve çözülme sırasındaki (e) SEM görüntüleri [29] 
Balık asalağı salgı lifleri yün liflerine benzer özellikler gösterseler de, yün liflerinde bulunan yüksek sülfür matrisleri bu salg1 liflerinde yoktur [24,27,31,32]. Hem yapıları hem de mekanik özellikleri ile diğer $\alpha$-keratin ara filamentleri içeren lifli yapılardan ayrılmaktadır [25,33]. Saç gibi doğal keratin içerikli protein lifinin çok hücreli yapılarının aksine balık asalağı salgısı lifleri tek bir hücre içerisinde oluşur $[9,25]$.

Balık asalağının yaşam şartları ve türü de salgı liflerinin üretim mekanizması üzerinde önemli bir rol oynamaktadır. Atlas Okyanusu türü olan M. glutinosa ile Pasifik Okyanusu türü olan Eptatretus stoutii balık asalaklarının karşılaştırıldığ 1 bir çalışmada, salg1 lifi kümelerinin çözülüş mekanizmalarında bazı farklılar gözlemlenirken, her iki türün de ortam sicaklığına ve tuz konsantrasyonuna karşı hassasiyet gösterdiği belirtilmiştir [12,20,34]. Ara filamentlerin oluşturduğu lif yumaklarındaki çözülmenin maksimum olduğu şartlar $5-10^{\circ} \mathrm{C}$ arası, $1.25 \mathrm{M}$ sodyum klorit konsantrasyonu olarak kaydedilmiştir [34].

\section{BALIK ASALAĞI SALGI LİFLERININ ÖZELLIKKLERİ}

Balık asalağı salgısı lifleri yüksek miktarlarda ara filament proteinlerinin bir araya gelmesi ile oluşmaktadır. Fakat bu liflerin özellikleri memelilerde bulunan yün, saç, tırnak gibi $\alpha$-keratin içeren diğer ara filamentli maddelerden tamamıla farklıdırlar [9,35]. Özellikle sulu ortamlarda ikisi arasındaki fark daha da net ortaya çıkmaktadır. Balık asalağı salgı lifleri, su içerisinde kauçuk gibi davranırken, $\alpha$-keratin içeren lifler sulu ortamda dahi serttir $[9,11,24,35]$. Salg1 lifleri ve $\alpha$-keratinler arasındaki farklılıkların, $\alpha$-keratinlerin içerisindeki ara filamentleri çevreleyen yüksek çapraz bağlı matris protein ağlarından kaynaklandığ 1 ve bunun sonucu olarak da yapıdaki ara filamentlerin sudan etkilenmesinin engellendiği düşünülmektedir $[9,35,36] . \quad \mathrm{Bu}$ nedenle balık asalağı salgısı lifleri, hem yaş hem kuru ortamlarda değerlendirilmekte, diğer liflerle kıyaslanması da aynı şekilde bu iki farklı ortam göz önüne alınarak yapılmaktadır (Şekil 4).

Oldukça yüksek mekanik özelliklere sahip olan balık asalağı salgısı lifleri bilinen en tok lifler arasında yer almaktadır, diğer bir değişle bu liflerin kopartılabilmesi için gerekli enerji miktarı son derece fazladır [11,35-37]. Balık asalağ liflerinin (kuru) yüksek kopma mukavemeti ortalama 467-570 MPa, kopma uzamasi 1.0 0.1 ve kopartılabilmesi için gerekli olan enerji $240 \pm 20 \mathrm{MJm}^{-3}$ civarındadır $[3,36]$.

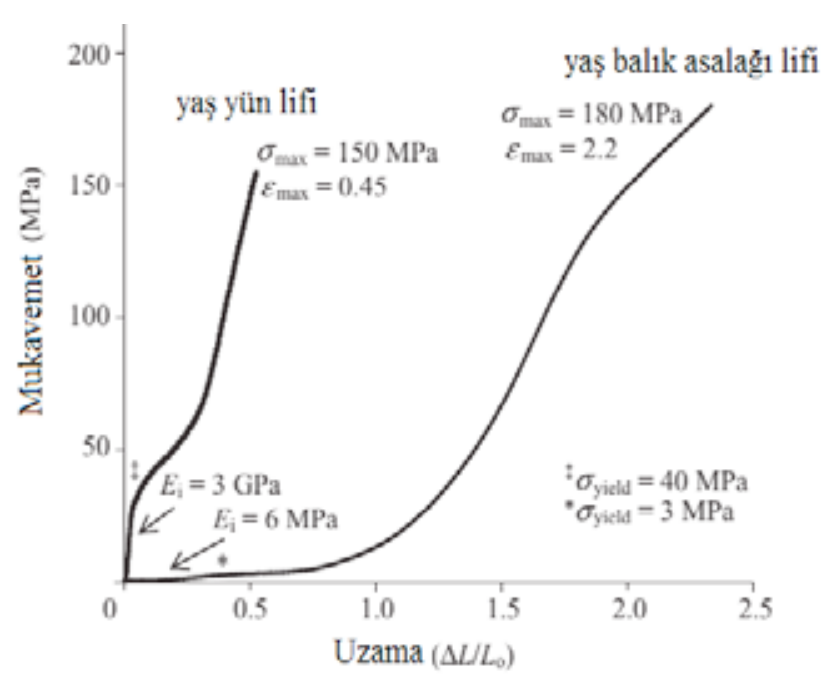

Şekil 4. Balık asalağı salgısı lifleri (yaş) ile yün liflerinin (yaş) mukavemet-uzama eğrilerinin karşılaştırılması [36]

$\mathrm{Bu}$ liflerin tokluk değerlerine en yakın değerler örümceklerden elde edilen lifler tarafindan sergilenmektedir [32]. Bu sebeple balık asalağı salgısı lifleri genellikle bu lifler ile kıyaslanmaktadır $[1,3,36]$. Balık asalağı salgısı lifleri ile mukayese edilen liflerden bir diğeri de midye fibrilleridir [Midyelerin birbirine bağlanmak için ürettikleri fibriller (Mussel byssal threads)]. Bu lifler balık asalağı lifleri (kuru) kadar uzayabilir olmasına rağmen ne mukavemetleri ne de toklukları bu lifler kadar yüksek değildir. Kolajen ve yün liflerinin her ikisi de balık asalağı liflerinden (kuru) çok daha az mukavemete, tokluğa ve uzayabilme yeteneğine sahiptir [36].

\%35'e varan oranlarda her hangi bir deformasyona uğramadan esnetilebildiğinden ve kuvvet kaldırıldığında tekrar eski uzunluğuna dönebildiğinden dolayı bu liflerin kauçuk benzeri bir davranış sergiledikleri belirtilmektedir $[9,13,37]$. Fakat $\% 35$ 'in üzerindeki uzamalar lif yapısında plastik deformasyona neden olmakta ve lif tekrar eski uzunluğuna dönememektedir (Şekil 5) [9,13].

Elastik davranıştan plastik davranışa geçiş, $\alpha$ sarmallarının parçalanıp $\beta$-levhalar biçimine dönüşmesine tekâmül etmektedir [32]. $\beta$-levhalarının oluşumu ile birlikte hidrojen bağlarının sayısı artmakta ve yüksek kopma mukavemetine sahip salgı lifleri oluşmaktadır [9,10,27,31]. Şekil 5'de balık asalağ 1 salgı bezleri tarafından üretilen ara filamentlerin yapısındaki alfa sarmal yapıların gerilim altında beta levhalara dönüşümü gösterilmektedir [38]. Sekil 5'de 1. Bölgede deformasyon neredeyse tamamen uç domainlerde (terminal domain) meydana gelmektedir. 2.bölgede çift kıvrımlı filament yapısı içerisindeki alfa 
sarmalları beta levhaları oluşturmak için açılmaya başlar. 3 . Bölgenin sonunda çift kıvrımlı filament yapısı içerisindeki tüm alfa sarmalları beta levhalar şeklinde uzar. 4.bölge gerilmeye, kaymaya ve son olarak beta levhalarının ve beta levha kristallerinin kopmasına karşılık gelir [18,27,35]. $\beta$-levhalar sayesinde oldukça yüksek kopma mukavemetine sahip olan bu lifler aynı zamanda 0.02 Pa'lık elastik modülü ile bilinen en yumuşak bio-materyaller arasındadır [9].

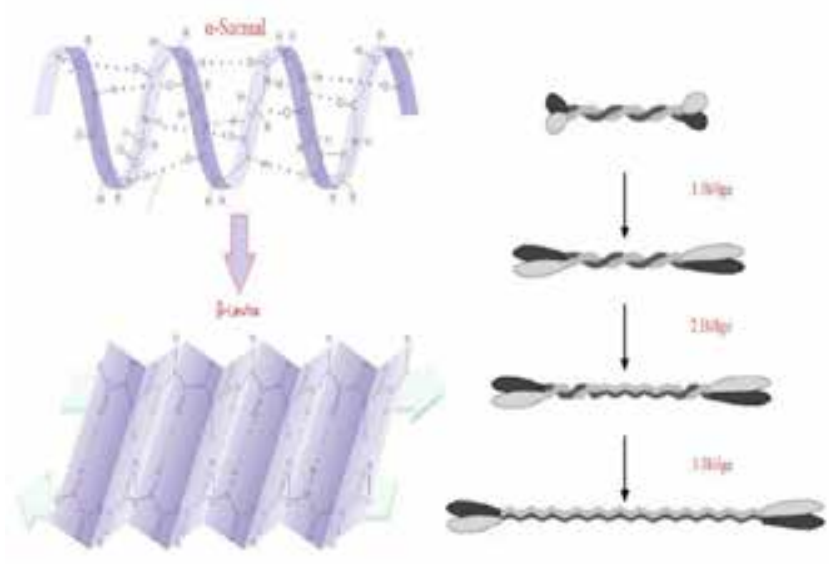

Şekil 5. Balık asalağı salgı bezleri tarafindan üretilen ara filamentlerin yapısındaki alfa sarmal yapıların gerilim altında beta levhalara dönüşümü [18,27,35,38]

Tablo 1. Çeşitli protein esaslı liflerin mekanik özellikleri [1,3,16,39-42]

\begin{tabular}{lccc}
\hline Malzeme & $\begin{array}{c}\text { Kopma } \\
\text { gerilimi } \\
\text { (MPa) }\end{array}$ & $\begin{array}{c}\text { Kopma } \\
\text { Uzaması } \\
\text { (mm/mm) }\end{array}$ & $\begin{array}{c}\text { Young } \\
\text { Modülü } \\
\text { (GPa) }\end{array}$ \\
\hline $\begin{array}{l}\text { Amiloid protein nano } \\
\text { lifleri }\end{array}$ & 326 & - & 14 \\
$\begin{array}{l}\text { Recombinant bal arıs1 } \\
\text { ipeği proteini }\end{array}$ & 150 & 0,5 & - \\
$\begin{array}{l}\text { Doğal örümcek ipeği } \\
\text { Recombinant örümcek } \\
\text { ipeği proteini }\end{array}$ & $800-1400$ & $0,2-0,3$ & - \\
$\begin{array}{l}\text { Balık asalağ1 salg1 } \\
\text { lifleri (kuru) }\end{array}$ & 508 & 0,2 & 21 \\
$\begin{array}{l}\text { Balık asalağ1 salgı lifle- } \\
\text { ri (esnetilmiş, kuru) }\end{array}$ & 706 & 0,4 & 8 \\
$\begin{array}{l}\text { Rejenere edilmiş balık } \\
\text { asalağ1 salg1 lifleri }\end{array}$ & 150 & 1,2 & 9,2 \\
$\begin{array}{l}\text { Insan kemiği (patellar } \\
\text { tendon) }\end{array}$ & 65 & 0,14 & 0,66 \\
\hline
\end{tabular}

\section{BALIK ASALAĞI SALGI LİFLERİ BIYYOMIMIIK MODEL ALINARAK YENİ LIFLERİN ÜRETIMİ}

Günümüz tekstil endüstrisinde kullanılan hammaddelerin çoğu sentetik materyallerden oluşmaktadır. Son yıllarda gittikçe önem kazanan sürdürülebilir üretim yaklaşımı petrol kaynaklı olan bu sentetik materyallerinin kullanımını sınırlamakta, bu maddeler yerine doğal ya da doğal türevli maddelerin kullanımı tercih sebebi haline gelmektedir. Konvansiyonel tekstil ürünlerinin üretiminde sentetik liflerin yerini doldurabilecek özelliklere sahip doğal ya da doğal kökenli lifler bulunabilmektedir. Ancak her geçen gün teknik tekstillere, katma değeri yüksek tekstil ürünlerinin üretimine önem veren tekstil endüstrisinde yüksek performans özelliklerine sahip doğal liflerin bulunabilmesi oldukça güçtür. Bugüne dek yüksek performans özelliklerine sahip doğal lif denildiğinde ilk akla gelen lif olan örümcek ipeği liflerinin üretimi her ne kadar doğadan esinlenilerek uygulanan yöntemlerle arttırılmış olsa da, tekstil endüstrisinin yüksek performanslı doğal esaslı lif ihtiyacını karşılayabilecek kapasiteye henüz ulaşılamamıştır [16].

Balık asalağı salgısı lifleri yüksek mukavemeti ve sıra dışı tokluk özelliği sayesinde tekstil endüstrisinin yeni biomimik modeli haline gelmiştir $[3,9,16]$. Habitatı gereği yetiştirilmesi neredeyse imkânsız olan bu deniz canlılarının yüksek performans özelliklerine sahip liflerinin üretilebilmesi için bugüne dek birçok araştırma yapılmış ve bu araştırmalara halen devam edilmektedir. Bugün laboratuvar ortamında üretilen balık asalağı salgısı lifleri, her ne kadar orijinal balık asalağı salık salgısı liflerinin performans özelliklerine erişememiş olsa da, yapılan araştırmalara göre bu liflerden üretilen yüksek performans özellikli ürünlerin hayatımıza girmesi çok da uzak görülmemektedir $[3,43]$.

Üretim mekanizmaları bakımından örümcek ipeği lifleri ile kıyaslandığında daha az karmaşı bir sisteme sahip olan balık asalağı salgısı liflerinin laboratuvar ortamında üretildiği birçok çalışmaya rastlamak mümkündür. Önceki çalışmalarda, balık asalağı salgısı proteinleri formik asit içerisinde çözülmüş ve hava ara yüzlü-elektrolit tampon çözeltisi içerisinde bir araya getirilmiştir. Fakat elde edilen liflerin mukavemetinin doğal salgı liflerinin mukavemet özellikleri ile karşılaştırılamayacak kadar düşük olduğu gözlemlenmiştir [3].

Vimentin, desmin ve glial fibriller asidik proteini (GFAP) gibi proteinlerin balık asalağı salgısı lifleri ara filamentlerinde bulunan $\gamma$ proteinleri ile yapısal benzerlik sergilediğinin keşfedilmesi ile doğal balık asalağı salgıs1 liflerinin sahip olduğu özelliklere yakın lifler 
üretilebilmesinde bu proteinlerinin kullanımı araştırılmıştır $[9,44,45]$.

Balık asalağı salgısı proteinlerine yapısal benzerlik gösteren Vimentin proteinlerinin kullanımının, balık asalağ 1 $\alpha$ ve $\gamma$ proteinlerinin birleştirilmesinden daha kolay olduğu kaydedilmiştir $[9,16]$. Ayrıca elde edilen liflerin mekanik özelliklerinin önceki çalışmalara nazaran çok daha iyi olduğu ve $\alpha-\beta$ geçişinin (gerilim altında $\alpha$ sarmallarının $\beta$ levhalara dönüşümü) doğal balık asalağı salgısı liflerinde gözlemlenene benzer yapıda olduğu belirtilmektedir $[9,16]$.

Balık asalaklarının salgı bezlerinin çalışma mekanizmasında hala tam netliğe kavuşturulamayan kısımlar olsa da, yüksek performanslı doğal protein liflerinin üretimi için bu deniz canlısı büyük önem taşımaktadır. Dünyanın farklı yerlerinde birçok bilim insanın ilgi odağ olan bu liflerin ticari olarak üretilmesi için de araştırmalar yapılmaktadır. Balık asalaklarının kültür olarak üretimi ve salgılarının toplanması neredeyse imkânsız olduğundan bu liflerin ticari üretimi için ara filament proteinlerinin laboratuvar ortamında üretilip çoğaltılabilmesi üzerine araştırmalar halen devam etmektedir [46,47]. Kanada'da Guelph Üniversitesi tarafından yürütülen bir araştırmada Örümcek ipeğinin üretiminde başarılı sonuçlar veren genetik olarak işlenmiş bakterilerin kullanımı, balık asalağı salgısı liflerinin üretiminde de denemekte yani balık asalağ 1 ara filament proteinlerini üreten DNA bakterilere aktarılarak, bu proteinin bakteriler tarafından üretilmesi amaçlanmaktadır [32,47,48]. Araştırmacılara göre, bu çalışmadan başarılı sonuçlar elde edilmesi halinde bu lifler; otomobillerin hava yastıklarından koruyucu giysilere birçok teknik tekstillerde kolaylıkla kullanılabilecek bir hammadde haline geleceği düşünülmektedir $[46,48]$.

\section{SONUÇ}

Sürdürülebilir üretim her geçen gün daha çok önem kazanarak dünyada birçok endüstri dalının aynı anda altını çizdiği bir konu halini gelmiştir. Birçok alanda olduğu gibi tekstil endüstrisinde de üretimin uzun vadede devamlılığının "Nasıl" sağlanabileceğinin cevabı araştırılmaktadır. Yenilenebilir kaynakların kullanımı, geri-dönüşüm, tekrar kullanılabilirlik, doğaya karışabilir hammaddelerin tercihi ya da ekolojik yöntemlerin kullanımı sürdürülebilir bir tekstil üretimi için dikkat edilmesi gereken parametrelerden sadece birkaçıdır. Petrol kaynaklı sentetik maddelerin doğaya karışmasının uzun yıllar alması ve azalan petrol rezervleri sürdürülebilirlik yaklaşımı içerisinde, bu maddelerin kullanımı yerine doğal ya da doğaldan türetilen maddelerin tercihine neden olmaktadır. Dünya genelinde tekstil üretiminde kullanılan liflerin halen üçte ikisini sentetik lifler oluştursa da, her geçen gün doğal liflerden sürdürülebilir yöntemlerle üretilen ürünlerin kullanımı konusunda insanlar bilinçlendirilmektedir. Konvansiyonel tekstil üretiminde sentetik liflerin muadili doğal ya da rejenere liflerin bulunması çok da zor görünmese de, konu teknik tekstiller için doğal hammadde temini olduğunda bu durum oldukça zorlu bir hal almaktadır. Çünkü bilindiği üzere günümüzde yüksek performans özelliklerine sahip doğal lif oldukça azdır ve bu liflerin üretimi tekstil endüstrisinin göz bebeği olan teknik tekstillerin üretimine yetecek kapasitede ve nitelikte değildir. Bugün birçok ülke konvansiyonel tekstil ürünlerinin üretimi yerine katma değeri yüksek teknik tekstilleri üretimini tercih etmektedir. Ancak teknik tekstillerde kullanılan hammaddelerin çok büyük bir çoğunluğunu sentetik materyaller oluşturmaktadır. $\mathrm{Bu}$ sebeple son yıllarda birçok araştırmacı teknik tekstil endüstrisinin sürdürülebilir hammadde ihtiyacına çözüm olabilecek kaynakları araştırmaktadır. Balık asalağı salgısı lifleri tam da bu noktada birçok bilim insanın ilgi odağı haline gelmiştir. Üstün kopma mukavemeti, tokluğu ve bununla birlikte şaşırtıcı derecede esnek yapısı sayesinde teknik tekstiller endüstrisinde ihtiyaç duyulan yüksek performanslı doğal lifler için oldukça iddialı bir aday olarak gösterilmektedir. Balık asalaklarının habitatından dolayı bu canlıların yetiştirilmesi nerdeyse imkânsız olduğundan geniş ölçekli üretimi de oldukça zordur. $\mathrm{Bu}$ sebeple örümcek ipeğinin üretiminde kullanıldığı gibi, balık asalağı liflerini oluşturan protein geninin bakterilere aktarılarak bu liflerin üretiminin bakteriler yardımı ile gerçekleştirilmesi hedeflenmektedir. Bu konuda henüz net bir sonuç elde edilememiş olsa da Kanada'daki Guelph Üniversitesi'nde araştırmalar halen devam etmektedir. Verilen bilgilere göre de balık asalağı salgı liflerinden üretilmiş teknik tekstillerin hayatımıza girmesi pek de uzak görülmemektedir.

\section{KAYNAKLAR}

[1] Fudge, D.S., Hillis S., Levy N., Gosline J.M. (2010). Hagfish slime threads as a biomimetic model for high performance protein fibres, Bioinspiration \& Biomimetics, 5, (3), 350.

[2] Lab, F. The production of fibers and films from solubilized hagfish slime thread proteins, http://www. comparativephys.ca/members/dfudge/publications/ production-fibers-and-films-solubilized-hagfishslime-thread-proteins, 2014)

[3] Negishi, A., Armstrong C.L., Kreplak L., Rheinstadter 
M.C., Lim L.-T., Gillis T.E., Fudge D.S. (2012). The production of fibers and films from solubilized hagfish slime thread proteins, Biomacromolecules, 13, (11), 3475-3482.

[4] Ferry, J.D. (1941). A fibrous protein from the slime of the hagfish, Journal of Biological Chemistry, 138, (1), 263-268.

[5] Zaccone, G., Dabrowski, K., Hedrick, M.S., Fernandes, J.M.O., Icardo, J.M. (2015). Phylogeny, Anatomy and Physiology of Ancient Fishes, CRC Press, Boca Raton

[6] Hearle, J.W. (2007). Protein fibers: Structural mechanics and future opportunities, Journal of Materials Science, 42, (19), 8010-8019.

[7] Prager, E. (2011). Sex, drugs, and sea slime: The oceans' oddest creatures and why they matter, University of Chicago Press.

[8] Bates, M. The creature feature: 10 fun facts about the hagfish, http://www.wired.com/2014/11/ creaturefeature10funfactshagfish/, (Haziran 2015)

[9] Fudge, D.S., Schorno S., Ferraro S. (2014). Physiology, biomechanics, and biomimetics of hagfish slime, Annual review of biochemistry, 84, 6.1-6.21.

[10] Ewoldt, R.H., Winegard T.M., Fudge D.S. (2011). Non-linear viscoelasticity of hagfish slime, International Journal of Non-Linear Mechanics, 46, (4), 627-636.

[11] Fudge, D.S., Levy N., Chiu S., Gosline J.M. (2005). Composition, morphology and mechanics of hagfish slime, Journal of Experimental Biology, 208, (24), 4613-4625.

[12] Knight, K. (2014). Adhesive constrains hagfish thread skeins, The Journal of Experimental Biology, 217, (8), 1199-1200.

[13] Hearle, J.W.S. (2009). 3 - an introduction to protein fibres, In: Eichhorn SJ, Hearle JWS, Jaffe M, Kikutani T (eds) Handbook of textile fibre structure, vol 2. Woodhead Publishing, 95-107.

[14] Lim, J., Fudge D.S., Levy N., Gosline J.M. (2006). Hagfish slime ecomechanics: Testing the gill-clogging hypothesis, Journal of Experimental Biology, 209, (4), 702-710.

[15] Winegard, T., Fudge D. (2010). Deployment of hagfish slime thread skeins requires the transmission of mixing forces via mucin strands, The Journal of Experimental Biology, 213, (8), 1235-1240.

[16] Pinto, N., Yang F.C., Negishi A., Rheinstädter
M.C., Gillis T.E., Fudge D.S. (2014). Self-assembly enhances the strength of fibers made from vimentin intermediate filament proteins, Biomacromolecules, $15,(2), 574-581$.

[17] Winegard, T., Herr J., Mena C., Lee B., Dinov I., Bird D., Bernards Jr M., Hobel S., Van Valkenburgh B., Toga A., Fudge D. (2014). Coiling and maturation of a high-performance fibre in hagfish slime gland thread cells, Nature Communications, 5.

[18] Fudge, D.S. (2002). The biomechanics of intermediate filament-based materials: Insights from hagfish slime threads, University of British Columbia,

[19] Winegard, T., Herr J., Mena C., Lee B., Dinov I., Bird D., Bernards Jr M., Hobel S., Van Valkenburgh B., Toga A. (2014). Coiling and maturation of a highperformance fibre in hagfish slime gland thread cells, Nature Communications, 5.

[20] Susan L. Edwards, G.G.G. (2015). Hagfish biology, CRC Press, Boca Raton, FL.

[21] Simon, M. Absurd creature of the week: This oceanic 'nightmare' suffocates foes with clouds of slime, http://www.wired.com/2014/05/absurd-creature-ofthe-week-hagfish/, (Haziran 2015)

[22] Kwok, R. Slime is the new silk, http:// conservationmagazine.org/2013/03/slime-is-thenew-silk/, (October 2014)

[23] Herr, J.E., Clifford A.M., Goss G.G., Fudge D.S. (2014). Defensive slime formation in pacific hagfish requires ca2+-and aquaporin-mediated swelling of released mucin vesicles, The Journal of Experimental Biology, 217, (13), 2288-2296.

[24] Kreplak, L., Fudge D. (2007). Biomechanical properties of intermediate filaments: From tissues to single filaments and back, BioEssays, 29, (1), 26-35.

[25] Hearle, J.W., Morton W.E. (2008). Physical properties of textile fibres, CRC Press, Cambridge.

[26] Winegard, T., Herr J., Mena C., Lee B., Dinov I., Bird D., Bernards Jr M., Hobel S., Van Valkenburgh B., Toga A., Fudge D. (2014). Coiling and maturation of a high-performance fibre in hagfish slime gland thread cells, Nat Commun, 5 .

[27] Levy, N. (2005). Hagfish slime: Fine-tuning the mechanical properties of a new high performance fiber, University of British Columbia,

[28] Ara filament, https://tr.wikipedia.org/wiki/Ara filament, (Haziran 2015)

[29] Koch, E.A., Spitzer R.H., Pithawalla R.B., Parry D. (1994). An unusual intermediate filament subunit from 
the cytoskeletal biopolymer released extracellularly into seawater by the primitive hagfish (eptatretus stouti), Journal of cell science, 107, (11), 3133-3144.

[30] Yalçın, A. (2012). Posttranslasyonel modifikasyon ve protein fonksiyonu.

[31] Fudge, D. (2012). Hagfish slime threads, In: The functional fold: Amyloid structures in nature. 15-33.

[32] Fu, J., Guerette P.A., Miserez A. (2015). Selfassembly of recombinant hagfish thread keratins amenable to a strain-induced $\alpha$-helix to $\beta$-sheet transition, Biomacromolecules, 16, (8), 2327-2339.

[33] Hearle, J.W.S. (2008). An alternative model for the structural mechanics of hagfish slime threads, International Journal of Biological Macromolecules, 42, (5), 420-428.

[34] Bernards, M.A., Oke I., Heyland A., Fudge D.S. (2014). Spontaneous unraveling of hagfish slime thread skeins is mediated by a seawater-soluble protein adhesive, The Journal of Experimental Biology, 217, (8), 1263-1268.

[35] Fudge, D.S., Gardner K.H., Forsyth V.T., Riekel C., Gosline J.M. (2003). The mechanical properties of hydrated intermediate filaments: Insights from hagfish slime threads, Biophysical Journal, 85, (3), 2015-2027.

[36] Fudge, D.S., Gosline J.M. (2004). Molecular design of the $\alpha$-keratin composite: Insights from a matrixfree model, hagfish slime threads, Proceedings of the Royal Society of London Series B: Biological Sciences, 271, (1536), 291-299.

[37] Fudge, D.S., Winegard T., Ewoldt R., Beriault D., Szewciw L., McKinley G. (2009). From ultrasoft slime to hard $\alpha$-keratins: The many lives of intermediate filaments, Integrative and comparative biology, 49, (1), 32-39.

[38] Carr, S.M. Secondary protein structure, http://www. mun.ca/biology/scarr/MGA2_03-18b.html, (Haziran 2015)
[39] Meier, C., Welland M.E. (2011). Wet-spinning of amyloid protein nanofibers into multifunctional highperformance biofibers, Biomacromolecules, 12, (10), 3453-3459.

[40] Weisman, S., Haritos V.S., Church J.S., Huson M.G., Mudie S.T., Rodgers A.J., Dumsday G.J., Sutherland T.D. (2010). Honeybee silk: Recombinant protein production, assembly and fiber spinning, Biomaterials, 31, (9), 2695-2700.

[41] Shao, Z., Vollrath F. (1999). The effect of solvents on the contraction and mechanical properties of spider silk, Polymer, 40, (7), 1799-1806.

[42] Reddy, N., Yang Y. (2014). Innovative biofibers from renewable resources, Springer.

[43] Hagfish slime as a model for tomorrow's natural fabrics, http://phys.org/news/2012-11-hagfish-slimetomorrow-natural-fabrics.html, (October 2014)

[44] Schaffeld, M., Schultess J. (2006). Genes coding for intermediate filament proteins closely related to the hagfish "thread keratins (tk)" $\alpha$ and $\gamma$ also exist in lamprey, teleosts and amphibians, Experimental Cell Research, 312, (9), 1447-1462.

[45] Riemer, D., Weber K. (1998). Common and variant properties of intermediate filament proteins from lower chordates and vertebrates; two proteins from the tunicate styela and the identification of a type iii homologue, Journal of cell science, 111, (19), 29672975.

[46] Hewitt, J. The ultimate biofilament: Hagfish slime, http://phys.org/news/2014-09-ultimate-biofilamenthagfish-slime.html, (October 2014)

[47] Barker, T.W. The biomimicry manual: What can designers learn from the hagfish about spandex?, http:// inhabitat.com/ebiomimicrymanualwhatcandesigners learnfromthehagfishaboutspandex/, (Haziran 2015)

[48] Lakhtakia, A., Martin-Palma R.J. (2013). Engineered biomimicry, Elsevier, Waltham. 